\title{
Development and application of a swine model for training ultrasonography-guided central venous access
}

\section{Desenvolvimento e aplicação de um modelo porcino para treinamento de acesso venoso central guiado por ultrassonografia}

Jackson Vinícius de lima Bertuol ${ }^{1}$ iD; Natasha lure Bueno Camargo ; Fernando Antonio Campelo Spencer Netto²; André Pereira WestPHALEN, TCBC-PR ${ }^{1}$.

\section{A B S T R A C T}

\begin{abstract}
Introduction: simulation based teaching is a powerful tool in medical education, allowing hands on practice under a controlled environment and with repeated maneuvers. Central venous access venipuncture is one of the most frequent procedures carried out in the hospital setting, due to its various clinical indications and, when performed with the help of ultrasonography, the risk of adverse events is minimized. Aim: to develop, to describe and to test a porcine model that simulates the central venous access puncture aided by ultrasonography. Method: a low cost porcine model was developed to train medical students and residents on central venous access guided by ultrasonography. Both students and medical residents underwent a theoretical training regarding the model, followed by a hands-on training session. Afterwards, the participants assessed the model by answering a questionnaire. Results: there were 51 participants. The average score regarding the similarity between the model and the human anatomy was 9.15. When the characteristics were separately assessed, the mean scores regarding the similarity of the vessels, anatomic disposition and ultrasonographic characteristics as well as the venipuncture were, respectively, 9.27; 9.31; 9.54 and 8.86. Conclusion: The model was approved and considered appropriate for the training of central venous venipuncture by all the participants. Furthermore, it is a low cost, simple and reproducible model, that presents high similarity with the human anatomy. Therefore, it may be used as an aid to train people on ultrasonography guided central venous access.
\end{abstract}

Keywords: Ultrassonography. Central Venous Catheters. Education, Medical. Simulation Technique.

\section{INTRODUCTION}

Sinting imulation-based teaching has become popular in training the skills of professionals in several areas, being a powerful learning tool in medicine. Simulation allows the practice of procedures in a controlled environment, in which error becomes an opportunity to improve learning, conferring greater autonomy to students and reducing risks to the patient ${ }^{1-4}$.

Central venous access is one of the most commonly performed medical procedures in clinical practice, approximately 200,000 of these procedures being performed annually in England ${ }^{5}$, and five million in the USA ${ }^{6}$. There indications for a central venous access are infusion of medications, parenteral nutrition, dialysis therapy, invasive monitoring in critically ill patients, and others ${ }^{7,8}$. Despite being considered a low complexity procedure that every doctor must be qualified to perform, it is not free of complications, the most common being infections associated with catheters, arterial puncture, pneumothorax, hematomas and venous thrombosis. The number of punctures to obtain success is directly proportional to the rate of complications ${ }^{7-9}$, whose incidence increases six-fold when three or more attempts are required ${ }^{10}$. As for the puncture sites, there is a preference for the internal jugular and subclavian veins, due to the higher rates of complications of central venous access in the femoral vein? 
Traditionally, central venous access has always been performed considering anatomical references. However, in the last 20 years, many studies have shown the benefits of using ultrasonography to guide the venipuncture. When aided by the ultrasonography, the puncture is performed with visualization of the vessels through the sonographic image, reducing the number of necessary punctures and the complication rates ${ }^{5-13}$. This fact is observed independently of the chosen puncture site (internal jugular, subclavian or femoral), although most of the studies are for internal jugular vein ${ }^{11}$. In view of all the positive evidence favoring the eco-guided puncture, in 2002, the National Institute for Clinical Excellence (NICE) recommended in its guideline that central venous access be carried out with the help of ultrasonography ${ }^{5}$. Several other organizations also issued this recommendation: American College of Surgeons, College's Committee on Perioperative Care, American Society of Anesthesiologists, American Society of Echocardiography, and Agency for Healthcare Research and Quality ${ }^{6}$.

Another factor that helps to reduce the number of complications is training and experience with the procedure. Professionals who have performed more than 50 central venous access have lower rates of complications than those who carried out less ${ }^{6,14}$. Thus, training in simulators is an attractive modality to guarantee dexterity to the professional before exposure to patients ${ }^{6,10}$. Studies using medical education based on the simulation of central venous access have demonstrated greater operator comfort and better performance, both in simulation and in patient care in real medical practice ${ }^{15}$. Current simulation methods mostly comprise commercial mannequins mimicking human anatomy. However, the use of such technology in teaching is hindered by the high acquisition and maintenance costs of such equipment ${ }^{6,15}$. In addition, many models available on the market are not realistic enough and do not simulate the ultrasonography characteristics of human tissues ${ }^{6}$. To circumvent the problem in question, especially in countries with few resources available in the area of health and education, professionals working in medical education have developed craft models for training, based mainly on animal parts and ballistic gelatin $^{6,15-18}$.

\section{OBJECTIVE}

To develop and describe an inexpensive experimental model for central venous access simulation guided by ultrasonography in the internal jugular vein, to apply it to students, and to assess teaching of the procedure and the resemblance to reality when using it.

\section{METHODS}

The project was developed in the State University of Western Paraná (UNIOESTE) and in the University Hospital of Western Paraná (HUOP), from November 2019 to February 2020, being approved by the institution's ethics committee under the certificate of appreciation No. 23233819.2.0000.0107, and comprised three stages: model development, training session and application of the questionnaire, and data analysis.

The study participants were interns from the fifth and sixth years of medical school and resident doctors in the specialties of general surgery and internal medicine. Each participant signed an informed consent term before the start of the training session.

\section{Porcine model}

We used porcine parts in the manufacturing of the models. We acquired them in a meat-marketing establishment duly regulated by the competent health surveillance institutions, and they were composed of skin, subcutaneous tissue and muscle of the animal's abdominal region (pancetta). Each model was made with two parts, placed on top of each other, fixed to a rigid wooden surface, and interspersed with a Penrose drain number two (mean diameter $12 \mathrm{~mm}$ ) for simulation of the internal jugular vein, and a 20 french Kehr drain for simulation of the common carotid artery. We sought to maintain the same anatomical relationship between the in vivo structures - internal jugular vein lateral and slightly anterior to the common carotid artery (Figure 1).

The Kehr drain was filled with a red dye artificially colored solution with for blood simulation, connected to a two-way connector equipment and coupled to a $10 \mathrm{~mL}$ syringe, which simulated arterial pulse by means of manual, intermittent pushing of the 
plunger. The Penrose drain was also connected to a twoway connector equipment, one of the ways was coupled to a $60 \mathrm{~mL}$ syringe, and the other, to a blood transfusion equipment and a 1,000 $\mathrm{mL}$ saline bottle. All the system was filled with the same solution for blood simulation. We used the $60 \mathrm{~mL}$ syringe to suck the drain solution for simulation of hypovolemic states and also to retrieve any air bubbles, while the connection to the bottle of solution was needed for replacing the volume lost by puncture holes, keeping the drain always full. In this way, we could use the same drain several times. (Figure 2).

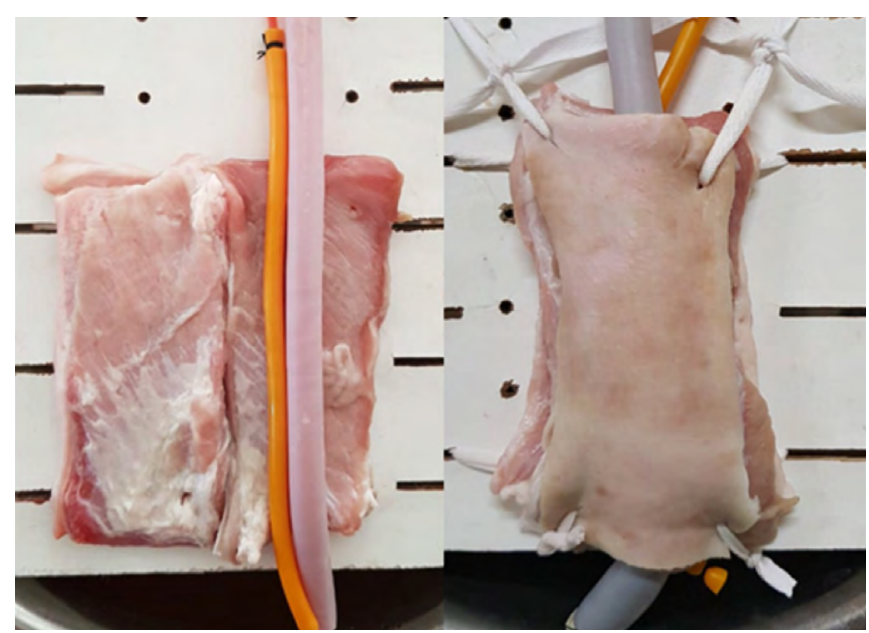

Figure 1. Placement of the drains on the porcine model.

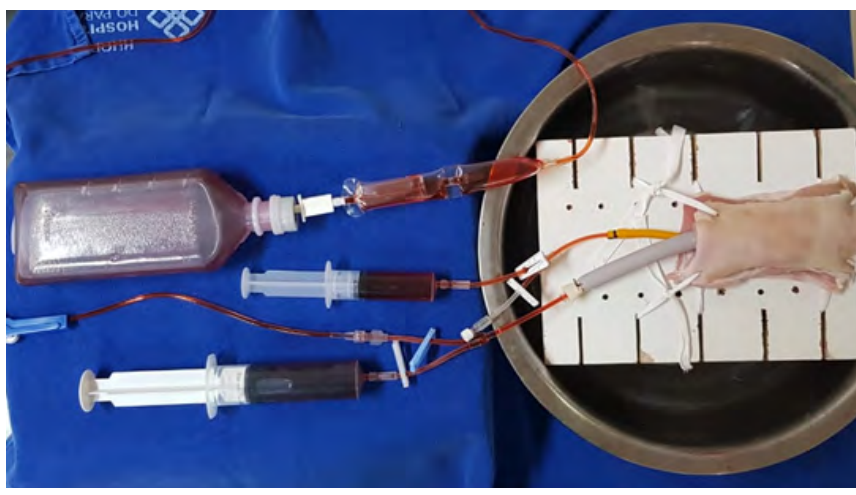

Figure 2. Composition of the model.

The HUOP Laboratory of Medical Skills provided all materials used but the porcine parts. There were no incurred costs, since they were materials with validity dates expired for use in clinical practice.

\section{Training session}

Each training session comprised groups of interns or resident doctors, and was divided into the following stages:

1. Theoretical discussion of the technique, indications and complications of central venous access;

2. Theoretical and practical discussion of the technical and anatomical concepts of the use ultrasonography to vessels punctures;

3. Practice of the echo-guided puncture in the porcine model, under supervision and critical and corrective analysis of the technique, when necessary;

4. Completion of the model evaluation questionnaire.

The practice was performed according to the technique described in the article and educational video published by The New England Journal of Medicine ${ }^{19}$, and the training ultrasonography images were acquired with VScan ${ }^{\mathrm{TM}} \mathrm{GE} \circledast$ apparatus, using a linear transducer with frequency between 4 and 8 Mhz (Figure 3).

The materials used for puncture were the same as those used in clinical practice to perform central venous access: $5 \mathrm{~mL}$ syringe and $18 \mathrm{GA}$ needle.

In addition to allowing echo-guided puncture, it was possible to complete the central venous access procedure: passage of a guidewire, dilator and catheter (Figure 4). For this study, however, we chose to evaluate only the puncture step.

\section{Questionnaire}

The evaluation questionnaire included epidemiological aspects of participants, previous training in central venous access with or without the aid of ultrasonography, adequacy of the model for training medical students and doctors, and importance of simulation models in medical education. Regarding the model, we requested evaluations in relation to its general similarity, to the similarity of the vessels image, of the anatomical arrangement, of the ultrasonography characteristics, and of the puncture itself. All questions varied in scores from zero to ten. The authors prepared 
the questionnaire, which did not undergo previous validation.

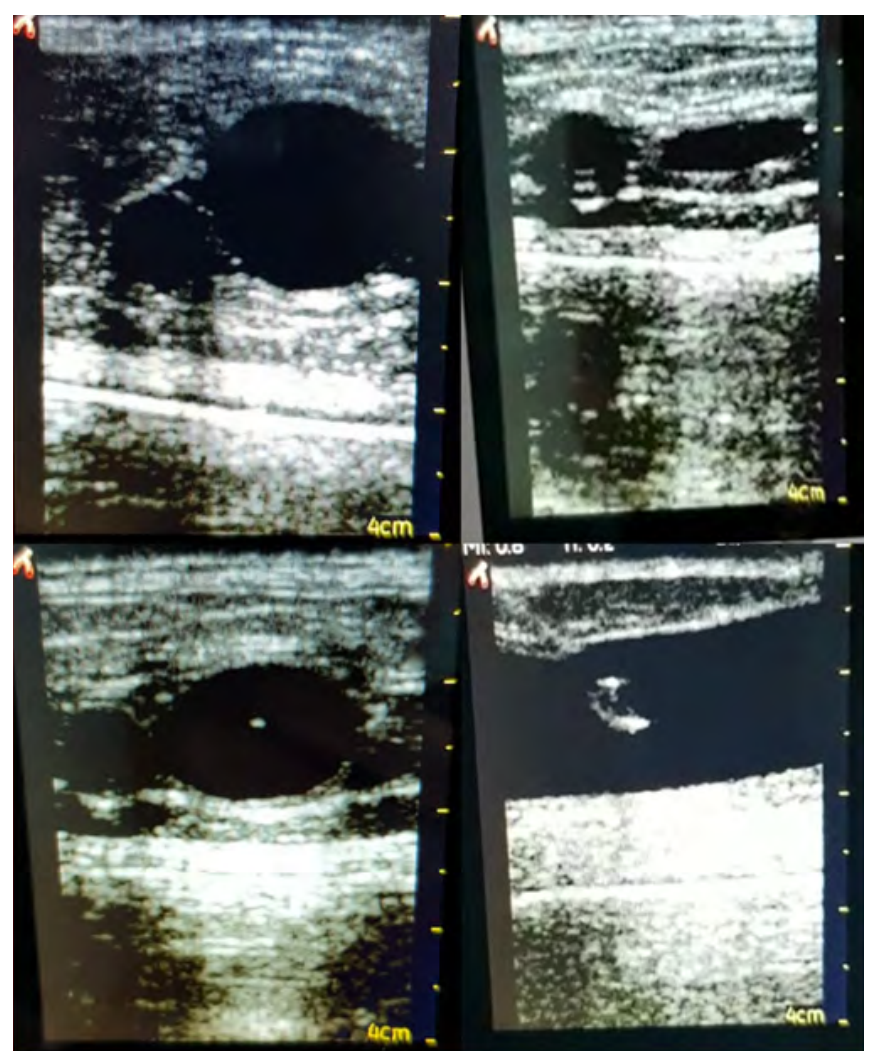

Figure 3. Ultrasonographic images of the venipuncture model. It is possible to observe the anatomic relationship between the vessels, the venous compression, the transversal and longitudinal venipuncture plane.

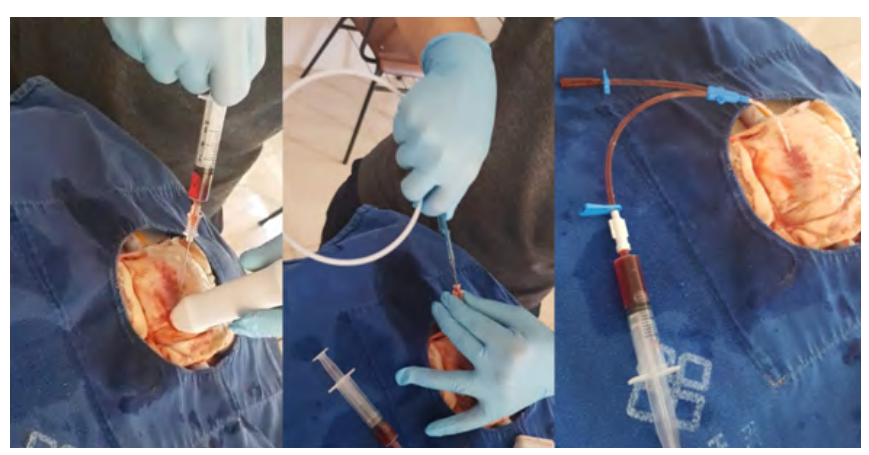

Figure 4. Venipuncture, guide wire and double lumen catheter insertions.

\section{Data analysis}

We loaded the data to Microsoft Excel® spreadsheets and analyzed them by means and percentage.
During the course of the study development phase, two medical experts with previous experience in eco-guided central venous access, a vascular surgeon and a intensive care physician, tested the model before applying it to students. Both approved it as a useful tool in training the procedure, and assigned a maximum score for all items, except for the similarity of the puncture, which received a score of eight by the vascular surgeon.

The assembly of the model and its operation can be observed by viewing the following videos: https:// www.youtube.com/watch?v=gHxiUDBUVe0 and https:// www. youtube.com/watch?v=0q1f8i3MrP0.

\section{RESULTS}

The research had 51 participants. Of these, 43 were medical graduates, and eight, resident doctors. As prior experience, most of the participants had performed between zero and less than five central accesses, and only eight had experience in performing the procedure with ultrasonography (Table 1).

Table 1. Demographics and Training Level.

\begin{tabular}{lc}
\hline Age - mean (range) & $26.03(21-40)$ \\
Gender - n (\%) & $24(47.05 \%)$ \\
Female & $27(52.4 \%)$ \\
Male & \\
Graduation Level - n (\%) & $43(84.31 \%)$ \\
Intern & $8(15.68 \%)$ \\
Resident & \\
Experience in central venous & \\
access - n (\%) & \\
None & $23(45.09 \%)$ \\
0-5 & $20(39.21 \%)$ \\
$6-10$ & $1(1.96 \%)$ \\
$>10$ & $7(13.72 \%)$ \\
USG experience - n (\%) & \\
Yes & $8(15.68 \%)$ \\
Not & $43(84.31 \%)$ \\
\hline
\end{tabular}


Regarding the evaluation of the model's quality and similarity with clinical practice, the average general similarity score was 9.15 . When divided by characteristics, the mean of the similarity scores of the vessels' image, anatomical arrangement of the structures, sonographic characteristics, and puncture were, respectively, 9.27, 9.31, 9.54, and 8.86 (Table 2).

Table 2. Evaluation of the model similarity.

\begin{tabular}{lcc}
\hline & $\begin{array}{c}\text { All } \\
\text { participants }\end{array}$ & $\begin{array}{c}\text { Participants } \\
\text { with previous } \\
\text { experience in } \\
\text { eco-guided } \\
\text { puncture }\end{array}$ \\
\hline $\begin{array}{l}\text { Sample size } \\
\text { Vessel image - } \\
\text { mean (SD) }\end{array}$ & 51 & 8 \\
$\begin{array}{l}\text { Anatomical } \\
\text { arrangement - } \\
\text { mean (SD) }\end{array}$ & $9.27(1.15)$ & $9.25(0.88)$ \\
$\begin{array}{l}\text { Sonographic } \\
\text { characteristics - } \\
\text { mean (SD) }\end{array}$ & $9.54(0.64)$ & $9.25(0.88)$ \\
$\begin{array}{l}\text { Puncture - mean } \\
\text { (SD) }\end{array}$ & $8.86(1.16)$ & $8.00(1.41)$ \\
$\begin{array}{l}\text { Overall similarity - } \\
\text { mean (SD) }\end{array}$ & $9.15(0.85)$ & $8.62(0.74)$ \\
\hline $\begin{array}{l}\text { SD = standard deviation. } \\
\text { (1.03) }\end{array}$ &
\end{tabular}

Considering only those participants who had experience with the eco-guided procedure, the average score of the overall similarity was 8.62 , and the similarity scores of the vessels image, anatomical arrangement of structures, sonographic characteristics, and puncture were, respectively, 9.25, 9.00, 9.25, and 8.25 (Table 2).

All participants approved the use of the model in learning eco-guided central access puncture and judged the training in the simulated experimental model as useful before performing the procedure in patients.

\section{DISCUSSION}

Classically, learning of procedures was based on the teaching model "see one, do one, teach one". However, in recent years, there has been increasing need of prior training in simulators before acting in real clinical situations ${ }^{6,20}$. This boosts the confidence of practitioners and reduces risks to patients, in addition to providing the correction of technical errors in a controlled environment, which allows for multiple iterations ${ }^{1-4}$. Moreover, that have been major advances in the development of models that simulate situations of actual medical practice ${ }^{21}$. Even so, many teaching centers are still based on the old methodology, mainly due to the lack of resources ${ }^{6,20}$. One way to get around this issue is the development of lowcost, handmade simulators, as described in this work.

We developed a low-cost, simulation model of eco-guided central venous access, of which all materials but for porcine parts are available in a hospital environment, and that could simulate the main characteristics of the procedure in patients: relationship between the artery and vein similar to human anatomy, adequate image of the vessels and maintenance of their ultrasonography characteristics - compressible vein and pulsatile artery, so that the performance of the procedure in the model was similar to clinical practice. In the vein puncture itself, the model allowed other essential steps in obtaining a central venous access: guide wire passage, dilation of the tissue, catheter insertion, and even simulation of hypovolemic states.

When evaluated, all participants accepted the model and considered it useful in teaching echo-guided venipuncture for central venous access, receiving high average scores. That is to say, the procedure performed with the model was very similar to reality. All participants also considered the teaching methodology based on simulation to be important before undergoing the procedure in patients. Therefore, this study confirms the importance of such a method in the development of medical skills in our students, rendering the learning process more reliable and enjoyable, as demonstrated in other works 1,18,22-27.

When compared with other handmade simulators described in the literature, the model developed in this work proved to be more similar to reality ${ }^{15,18,23}$. It utilizes biological tissue with characteristics similar to the human tissues, mimics the relationship between artery and vein, as well as the ultrasonography characteristics, and also allowing the puncture, guide wire passage, and catheter insertion. Thus, the model simulates the real situation better when compared with others. Nachshon et al. developed a model based on parts of chicken and balloons, and compared it to a synthetic mannequin. Both 
had mean reality similarity scores below $70^{15}$. Other models described also used chicken parts, vascular prostheses ${ }^{14}$ or ballistic gelatin as a base ${ }^{18}$, but the similarity with reality was not evaluated.

The models available in the Brazilian market for training of central venous access can cost more than $\mathrm{R} \$$ 10,000.00 (around US\$ 2,000.00), an unreal amount for most public education centers. The only cost to develop the model was the acquisition of the porcine parts. Nonetheless, the cost to assemble it, if all materials were to be bought, was estimated at $R \$ 50.00$ (around US\$10.00), allowing usage for several times, only changing the Penrose drain and the needles. In this study, we used the same porcine parts, since they were frozen, and the same Kehr drain during all training. The Penrose drain and needles were replaced at each training session (approximately every ten punctures) so that the average value per participant was lower than $R \$ 2.00$ (around US\$ 0.40).

Among all the assessed items, the one with the lowest average score was the puncture similarity (8.86 and 8.25). We believe that this was due to the greater resistance of the porcine skin when compared with the human, a problem that can be minimized by using parts of younger animals and with less thick skin. Furthermore, during model development and testing prior to training, we observed that the Penrose drain lost the ability to keep the wall tension after about ten punctures, a fact that hampers puncturing. Another fact observed was the progressive loss of the needle bevel edge, decreasing the cutting capacity, a fact that also hinders the perforation of tissues, especially the skin. For these reasons, we decided to substitute such materials every ten procedures, or earlier if necessary.
Despite the importance of central venous access training, since it is a procedure widely performed in medical practice and has complication rates that can reach up to $11 \%$ and be potentially fatal ${ }^{7}$, there are few described training models that are of low cost and have a high similarity to reality. Since the model presented in this work displays such characteristics, it becomes attractive in teaching the procedure, especially in centers where there is a shortage of resources for the acquisition of commercial simulators.

However, our study is not without limitations. The practice in simulators in generally performed in controlled environments, not generating the stress present in real situations. The sample size was relatively small and all participants were students or residents of the same institution. In addition, most study participants were inexperienced with the use of ultrasonography and had low experience in performing central venous access in patients, requiring the evaluation of the model by professionals with experience and the comparison with other models that simulate the same procedure.

\section{CONCLUSION}

We developed a simple, inexpensive and reproducible simulation model, which showed high resemblance to reality in the main features needed for a central venous access puncture guided by ultrasonography. It was approved by all study participants as a useful model in learning the procedure. Thus, the developed model can be used as an adjunct in the training of physicians and medical graduates.

\section{R E S U M O}

Introdução: o ensino baseado em simulação é poderosa ferramenta para o aprendizado na educação médica, permitindo a prática de procedimentos em ambientes controlados e por repetidas vezes. A realização de acesso venoso central é um dos procedimentos médicos mais realizados em ambiente hospitalar, tendo várias indicações e, quando realizada com o auxilio da ultrassonografia, os riscos das complicações do procedimento são minimizados. Objetivo: desenvolver, descrever e aplicar um modelo porcino para simulação de acesso venoso central guiado por ultrassonografia. Métodos: modelo porcino de baixo custo foi desenvolvido para treinamento de acesso venoso central guiado por ultrassonografia. Estudantes de medicina e médicos residentes receberam treinamento teórico em relação ao procedimento, seguido de treinamento prático no modelo. Posteriormente, os participantes avaliaram o modelo desenvolvido por meio de um questionário. Resultados: o estudo contou com 51 participantes. O escore médio de semelhança geral do modelo com a realidade foi 9,15. Quando separadas por características, as médias dos escores de semelhança da imagem dos vasos, da disposição anatômica das estruturas, das características ultrassonográficas e da punção foram, respectivamente, 9,27; 9,31; 9,54 e 8,86. Conclusão: o modelo foi aprovado e considerado útil para treinamento do procedimento por todos os participantes, além de ter baixo custo, ser simples, reprodutivel e apresentar alta semelhança com a realidade, podendo ser utilizado como adjunto no treinamento de acesso venoso central guiado por ultrassonografia.

Palavras chave: Ultrassonografia. Cateteres Venosos Centrais. Educação Médica. Simulação. 


\section{REFERENCES}

1. Spencer-Netto FAC, Silva MTB, Constantino MM, Cipriani RFF, Cardoso M. Projeto de ensino: modelo porcino de baixo custo para treinamento de dissecção venosa. Rev Col Bras. 2017;44(5):545-8.

2. Beaubien J, Baker D. The use of simulation for training teamwork skills in health care: how low can you go? Qual Saf Health Care. 2004;13(1):i51-6.

3. Heitz C, Eyck RT, Smith M, Fitch M. Simulation in medical student education: survey of clerkship directors in emergency medicine. West J Emerg Med. 2011;12(4):455-60.

4. Dourado A, Giannella T. Ensino baseado em simulação na formação continuada de médicos: análise das percepções de alunos e professores de um Hospital do Rio de Janeiro. Rev Bras Educ Med. 2014;38(4):460-9.

5. National Institute for Health and Care Excellence. Guidance on the use of ultrasound locating devices for placing central venous catheters [Internet]. London: NICE; 2002 [acessado 2020 Jan]. Disponível em: https://www.nice.org.uk/guidance/ta49.

6. Denadai R, Toledo AP, Bernades DM, Diniz FD, Eid $F B$, Landranchi LMMM, et al. Simulation-based ultrasound-guided central venous cannulation training program. Acta Cir Bras. 2014;29(2):132-44.

7. Grahan AS, Ozment C, Tegtmeyer K, Lai S, Braner DAV. Central Venous Catheterization (Videos in Clinical Medicine). N Engl J Med. 2007;356(21):e21.

8. Smith RN, Nolan JP. Central venous catheters. BMJ. 2013;347:f6570.

9. Abboud PAC, Kendall JL. Ultrasound guidance for vascular access. Emerg Med Clin N Am. 2004;22(3):749-73.

10. McGee DC, Gould MK. Preventing complications of central venous catheterization. N Engl J Med. 2003;348(12):1123-33.

11. American Society of Anesthesiologists Task Force on Central Venous Access; Rupp SM, Apfelbaum JL, Blitt C, Caplan RA, Connis RT, Domino KB, Fleisher LA, Grant S, Mark JB, Morray JP, Nickinovich DG, Tung A. Practice guidelines for central venous access: a report by the American Society of Anesthesiologists Task Force on Central Venous Access. Anesthesiology.
2012;116(3):539-73.

12. Leung J, Duffy $M$, Finckh $A$. Real-time Ultrasonographically-Guided Internal Jugular Vein Catheterization in the Emergency Department Increases Success Rates and Reduces Complications: a randomized, prospective study. Ann Emerg Med. 2006;48(5):540-7.

13. Lamperti $M$, Bodenham $A R$, Pittiruti $M$, Blaivas $M$, Augoustides JG, Elbarbary $M$, et al. International evidence-based recommendations on ultrasoundguided vascular Access. Intensive Care Med. 2012;38(7):1105-17.

14. Sznajder Jl, Zveibil FR, Bitterman $H$, Weiner $P$, Bursztein S. Central vein catheterization. Failure and complication rates by three percutaneous approaches. Arch Intern Med. 1986;146(2):259-61.

15. Nachshon A, Mitchell JD, Mueller A, BannerGoodspeed VM, McSparron J. Expert evaluation of a chicken tissue-based model for teaching ultrasoundguided central venous catheter insertion. J Educ Perioper Med. 2017;19(1):E503.

16. Pérez-Quevedo O, López-Alvarez JM, LimiñanaCañal JM, Loro-Ferrer JF. Design and application of model for training ultrasound-guided vascular cannulation in pediatric patients. Med Intensiva. 2016;40(6):364-70.

17. Jussila J. Preparing ballistic gelatine--review and proposal for a standard method. Forensic Sci Int. 2004;141(2-3):91-8.

18. Di Domenico S, Santori G, Porcile E, Licausi M, Centanaro $\mathrm{M}$, Valente $\mathrm{U}$. Inexpensive homemade models for ultrasound-guided vein cannulation training. J Clin Anesth. 2007;19(7):491-6.

19. Ortega R, Song M, Hansen CJ, Barash P. Videos in clinical medicine. Ultrasound-Guided Internal Jugular Vein Cannulation. N Engl J Med. 2010; 362(16):e57.

20. Ma IW, Teteris E, Roberts JM, Bacchus M. Who is teaching and supervising our junior residents' central venous catheterizations? BMC Med Educ. 2011;11:16.

21. Farjad Sultan S, Shorten G, Iohom G. Simulators for training in ultrasound guided procedures. Med Ultrason. 2013;15(2):125-31.

22. Robertson $B$, Kaplan $B$, Atallah $H$, Higgins $M$, Lewitt MJ, Ander $D$. The use of simulation and a modified 
Team STEPPS curriculum for medical and nursing student team training. Simul Healthc. 2010;5(6):3327.

23. Miranda RB, Nardino EP, Gomes T, Farias P. New technique for ultrasound-guided vascular access training using an animal tissue model. J Vasc Bras. 2012;11(1):83-7.

24. Takayesu JK, Farrell SE, Evans AJ, Sullivan JE, Pawlowski JB, Gordon JA. How do clinical clerkship students experience simulator-based teaching? A qualitative analysis. Simul Healthc. 2006;1(4):215-9.

25. Spencer-Netto FAC, Sommers CG, Constantino

Received in: 15/03/2020

Accepted for publication: 09/04/2020

Conflict of interest: no.

Funding source: none.
MM, Cardoso M, Cipriani RFF, Pereira RA. Projeto de ensino: modelo suíno para treinamento de drenagem torácica. Rev Col Bras Cir. 2016;43(1):603.

26. Spencer-Netto FAC, Zacharias P, Cipriani RFF, Constantino MM, Cardoso M, Pereira RA. Modelo porcino no ensino da cricotiroidotomia cirúrgica. Rev Col Bras Cir. 2015:42(3):193-6

27. Wang $E E$, Beaumont J, Kharasch M, Vozenilek J. Resident response to integration of simulation-based education into emergency medicine conference. Acad Emerg Med. 2008;15(11):1207-10.
Mailing address:

Jackson Vinícius de Lima Bertuol

E-mail: jvlbertuol@hotmail.com/jvlbertuol@hotmail.com

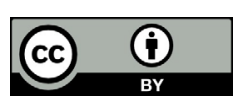

